\title{
AN EFFECT OF PSYCHOLOGICAL CONFLICT TO ELSA PERSONALITY DEVELOPMENT IN FROZEN: PSYCHOLOGICAL APPROACH
}

\author{
$\operatorname{Marson}^{1}$ \\ Universitas Putera Batam (UPB), Batam, Indonesia \\ pb161210001@upbatam.ac.id \\ Tomi Arianto ${ }^{2}$ \\ Universitas Putera Batam (UPB), Batam, Indonesia \\ Tomi.arianto@puterabatam.ac.id
}

\begin{abstract}
In this research, the researcher was focusing on the psychological conflict and the character development in which it could be found in the character of Elsa in Frozen. There were two theories that the researcher used for the research problems in this research. The first theory that the researcher used to answer the first research problem was about the psychological conflict that was proposed by Kurt Lewin to find variety of psychological conflict that was expressed by the character of Elsa in the story itself. As for the second theory that the researcher used to answer the second research problem was about the personality development which was proposed by Elizabeth B. Hurlock to explain the effect of psychological conflict to Elsa personality development. In this research, the researcher used descriptive qualitative method. The result of this analysis showed that there were two kinds of psychological conflict which was shown in Elsa character which were approach-avoidance conflict and avoidance-avoidance conflict and those two conflicts which gave a huge effect to Elsa personality development in which the researcher found that there are five determinants they are emotional, aspiration and achievement, intellectual, social, and family.
\end{abstract}

Keywords: character, character development, psychological conflict.

\section{INTRODUCTION}

In this literary works, the researcher found the fact that the character of Elsa having changes from the beginning of the story to the end of the story. The changes are known as character or personality development. Forster stated that character or personality development is mostly about the changing of the behavior of a person whether to a good behavior to a bad behavior or from bad behavior to a good behavior. Meanwhile in psychology aspect, the character or personality development is the pattern or a behavior of a person to change their attitude which makes themselves a different person.

In a developing process of a character, people tend to disposed by internal and also external factors. The internal factors are usually involved in the inner side of a person which is the behavior of a person. Things like individual personality behaviors, character, and inheritances are all dispositional issues. That are the things that usually come from the inside of a person which they don't have much control over it. Meanwhile, as for the external factors usually it involve in the place or environment which could influence or affect anything around us. In the other words, The internal factors is within an individual self and for external factor is from the outside of an individual which could influence them in every way depend on where they are. Psychological conflict could be included as one of the internal factors 
as a proof that psychology is usually involve within a person itself that could make a personality changes within themselves.

There is various kind of literary work that presented about the story of psychology like conflict, fear, personality changes, etc. One of the most famous stories was shown in the Frozen by Walt Disney Animation Studio. One of the reasons why the researcher chose this novel to be analyzed is because this is one of the Disney novels that the researcher interested in the story itself not just by the story but also about the relationship in the story itself. Just like how people know that all the Disney's literary works mostly are about the relationship or a love life between a man and a woman, such as Cinderella, Beauty and the Beast, and so on. So, because this is the first Disney novel that the researcher is interested in, the researcher becomes more interested in analyzing it.

From the explanation above, the researcher could formulate some question, they are: (1) what kind of psychological conflicts that can be found in the character of Elsa in the Frozen? (2) How are the psychological conflicts affect to Elsa character or personality development in the Frozen?

Based on the research problems above, the purposes of the study could be declared as follows: (1) To find out the kind of psychological conflict that can be foundin the character of Elsa in the Frozen (2) To explain the effect of psychological conflict to Elsa's character or personalitydevelopment.

Theoretically, this study would enrich the issues related to literature which is about psychology and children's literature development. Practically, the researcher would also hope that the outcome of this research could improve the knowledge about the psychology problem to the next researchers, especially about the psychological conflict and character or personality development. The researcher also hoped that this study could help all of students and lecturers in the English Literature Department to have more enormous understanding about the psychology of literature.

\section{LITERATURE REVIEW}

\subsection{Character Development}

There are two kind of factors that could influenced an individual character or personality development they are internal and external factors (Hurlock, 1976). Internal factor is the influential factor that comes from an individual self, while the external factor comes from the outside of a person, such as the attitude of people to another person whether it is bad or good. There are also eight kinds of determinants in which it could influence an individual character personality development. They are physical, intellectual, emotional, social, aspiration and achievement, sex, educational and family (Hurlock, 1976).

a. Physical Determinant

Physical determinant are about self-evaluation and self-concept toward an individual form (Hurlock, 1976). Attractiveness, body shape, the looks of a person and health are included as Physical determinant which means that an individual personality development could be affected by those physical determinants.

b. Intellectual Determinant

Intellectual capacity is mostly about the influences in a person personality that directly affect through the kind of life adjustments. The individual makes an indirect judgment through the others based on the intellectual achievement (Hurlock, 1976). It means that the 
person's intellectual capacity could affect a person personality or character development. In addition, the smarter a person determines their ability to decide when facing a problem, the more they are considered smart by other people determines on how they make their attitudes toward other person.

c. Emotional Determinant

Emotion Determinant is one of the important aspects that could affect a person through social or personal life of a person. Hurlock (1976) stated that dispossession of love had a disturbing effect on personality which means that the more love a person receives the happier and betters the person is. Social judgments could be influenced an individual personality through their own ability in order to establish emotional relationship with others.

\section{d. Social Determinant}

The lack of social approval has a huge negative impact on the personality of a person and that makes people fall below the average in the approval of people, so that there are a lot of methods to improve their approval has been tried (Hurlock, 1976). It means that the social judgments and approval could influence the personality or a character development. If a person wishes to be acknowledged in social life, they have to be able to become accustomed in that social life. Otherwise, if a person cannot adjust to the social life of their own environment or does something prohibited that is mismatched with what the environment wants, then they will not be accepted by that environment.

e. Aspiration and Achievement

Hurlock (1976) stated that aspirations involve in the ego of a person goals that they set for themselves. The more their aspiration involve in their ego, the more they relate to the manners that are important for them, the greater the influences of a person on their personality. It means that a person's aspiration has an influence toward an individual personality development. The higher the aspiration of that person, the higher the ego of a person in order to achieve the goal, then it will gradually influence that person's personality.

f. Sex Determinant

According to Hurlock (1976), Sexual behavior comes from an individual attitude toward sexual behavior and also the attitude of an important person in their life. It means that the influence of sexual behavior usually comes from the way a person behaves toward a specific person through the environment they are in.

g. Educational Determinant

Hurlock (1976) state that the greatest the influence of an educational institution could determine by a student's attitudes toward their teachers and toward the value of education through schools and college. Means that when student attitudes are negative, they usually complain a lot on any small problem that they had in school and they might even develop the fear on going to school.

h. Family Determinant

According to Hurlock (1976), the family the most important key to a child personality development. The influence usually comes from the lack of communication. It means that the influence of family on personality development of a child comes from the way a child behavior that are being molded by their own family and how the communication between the person with their family members.

\subsection{Psychological Conflict}

Conflict is regularly related with fights between two people or more. It means that conflict usually happens 
between two people or more due to their disagreement on something. On the other hand, the conflict is not just between two people or more but conflict can also occur within an individual self. Bruno (2002) stated that psychological conflict exists when we are forced to make difficult choices in life. It means that psychological conflict occurs when we were given difficult choices to choose.

Lewin (1957) state that psychological conflict is divided to three different types, they are: Approach-approach Conflict: this conflict usually happens when a person was given two choices to choose. Approach-avoidance Conflict: This conflict happens when a person has to deal with both desirable and also undesirable aspect which mean when a person senses a similar amount of attraction towards a goal. Avoidanceavoidance Conflict: this conflict happen when each of the challenging choice possesses negative consequence, that is, they are equally repulsive

\subsection{Previous Research}

The researcher utilizes a number of people works which have a correlated topic with the issue that is going to be discussing as assessment and reference. In the first previous research which was composed by Moawad (2016) that analyze about "A Study of Wole Soyinka's play The Lion and the Jewel in the light of cultures in conflict" The resemblance is the researcher by means of using psychological approach and the differences is the researcher is using the novel as the object of the research meanwhile in the journal of Moawad (2016) using the play or drama as the object of the research.

In the second previous research which was composed by Fabdriah \& Zakrimal (2017) that is about "The
Analysis of Heathcliff Character in Wuthering Heights by Emily Bronte: A Sigmund Freud's Theory". The resemblance in this research is by mean of using psychological approach and qualitative method. Meanwhile the differences is that the researcher using the theory of Lewin (1957) and Hurlock (1976).

In the Third Previous research which was composed by (Arianto \& Ambalegin, 2019) that is about "Suicide Experiments Due to Unmet Love Needs in Jhumpa Lahiri's Hell-Heaven Story" The resemblance in this research is by mean of using psychological approach and qualitative method. Meanwhile the differences is that in this previous research used the theory of Maslow (1954).

\section{RESEARCH METHOD}

This research used the qualitative research method. According to Drislane \& Parkinson (2011), qualitative research is using methods such as participant observation or case studies which result in a narrative, descriptive account of a setting or practice. In this research, the researcher collected the data from the novel that has been read more than once.

The main instrument of this research was the researcher himself. The researcher conducted all the observations from the main character in the Frozen novel, collected the data and analyzed the data by using the theories which have been explained in chapter 2. This research used the animated novel from Walt Disney entitled Frozen and the dialogue of that novel as the source of data, and the data were the dialogues and expressions which were related to the main character in Frozen novel.

There were some steps that the 
researcher did in order to collect the data. First, the researcher read the novel, and the researcher focused to the dialogues of the main character, Elsa. Second, the researcher focused to find the psychological conflicts and influence of fear that happen to Elsa as the main character of that Frozen novel as data collections. And the third step, the researcher tried to find the journals and theories from other experts which had relation toward the research topic to make this research valid.

There were some steps that the researcher conducted in collecting the data of this research, those were: 1) The researcher tried to review the data which have been collected; 2) The researcher classified the data that dealing with the research problems; 3 ) The researcher analyzed the data using the theories which have been explained in chapter II, those were psychological conflict theory by Lewin (1957) to answer the question 1 of research problems, and theory of personality development by Hurlock (1976) to answer the question 2 of research problems; 4) Finally, the researcher drew the conclusion after the data have beenanalyzed.

\section{FINDING AND DISCUSSION}

\subsection{Psychological Conflict}

In Frozen film, from three kinds of psychological conflict, the researcher found only two kinds of psychological conflict and they were approachavoidance conflict and avoidanceavoidance conflict.

\section{a. Approach-Avoidance Conflict}

There was a moment that related to this kind of psychological conflict. That was when Elsa and Anna had conversation during the party of Elsa's coronation day. Anna said to Elsa that she was very happy about being in the party with so many people around them and also hopes that they would be like that forever. Elsa was also very happy about the fact that Anna is happy, but then she refused it.

Elsa: Are you okay?

Anna: I've never been better. This is so nice. I wish it could be like this all thetime.

\section{Elsa: Me too. But it can't.}

Anna: Why not? If-

Elsa: It just can't. (Nathan \& Roman, 2013)

In this conversation, Elsa is having the approach-avoidance conflict experience in which there are two options. The first option was positive which is about Elsa thought that if she had people including Anna around her, having party with people in the kingdom, she would be happy and never been alone anymore. She was happy about it. While the second option was negative which shows that Elsa is afraid of her own power being shown up if she had so many people around her, she was afraid to hurt anyone, especially Anna.

\section{b. Avoidance-Avoidance Conflict}

There was moment which related to this conflict. It happens when Elsa and Anna are having a debate because of Anna's sudden marriage plan in the ballroom. At that moment, Anna asked Elsa for the blessing for the sudden marriage plan with prince Hans. Prince Hans was a man who she just met the day. When Elsa refused to wish her happy for her marriage plan, Anna was trying to arguing with her and made Elsa scared.

Anna: What did I ever do to you?! Elsa: Enough, Anna.

Anna: No. Why? Why do you shut me out?! Why do you shut theworld out?! What are 
you so afraidof?!

Elsa: I said, enough! (Nathan \& Roman, 2013)

In that moment, Elsa had no choice but to resist her fear so that her power will not be exposed. But the more she resisted her own fear, the more fear she got because of Anna who was still argued with her with many questions that she could not even answered it which made her situation worse and at the end, her power was exposed.

\subsubsection{The Effect of Psychological conflict to Elsa character development}

After analyzing the Frozen novel, the researcher found out that there were five kinds of determinants that has been explain above which related to Elsa. They were intellectual determinant, emotional determinant, social determinant, aspiration and achievement, and family determinant.

a. Intellectual Determinant

In Frozen novel, Elsa being a queen proof that she was a smart girl. In that story, it was shown that Elsa had an intellectual capacity as a proof that she made decisions when she was having problem. The first moment that showed Elsa's intellectual capacity was when she was in the coronation day. Elsa tried to resisting her fear and held her own magical power in order to go through the day in coronation ceremony. She used the spell that was given by her father, the King, when she was a child.

Elsa: Don't let them in. Don't let them see. Be the good girl you always have to be. Conceal. Don't feel. Put on a show. Make one wrong move and everyone will know. (Nathan \& Roman, 2013)
In that statement, Elsa wanted to hold something with her hands without wearing gloves that she has been always wearing in order to lock her magical power. She did it purposely so that she can resist her power for not being exposed in front of the crowd in the ballroom because of the psychological conflict she had at that time. There is another moment where the psychological conflict's influence Elsa's intellectual capacity which was shown when Anna came to find her at an ice castle on the north mountain.

Anna: I'm so sorry about

what happened. If I'd

known-- Elsa backs up, away fromAnna.

Elsa: No, it's okay. You don't

have toapologize, but you should probably go, please.

Anna: But I just gothere.

Elsa: You belong in Arendelle.

Anna: So doyou.

Elsa: No, I belong here. Alone.

Where I can be who I am

without hurting anybody.

(Nathan \& Roman, 2013)

In that scene, the last sentence Elsa said was a proof that she made a decision that she wanted to leave Arendelle and lived alone on the north mountain. She decided to live alone because she thought that with becoming alone, she would be able to become herself without hurting anyone. She also decided to live alone on the north mountain because she wanted to protect Anna from herpower.

b. Emotional Determinant

The psychological conflict also influenced to Elsa's emotions. The conflict of her and her fear made Elsa could not control her own emotion. She became anxious and scared easily because of that. Elsa's fear on her own 
power increased right after the death of her parents. So the more fear of Elsa's grew in her mind the more difficult she controlled her own emotions.

There was a moment that showed Elsa could not control her own emotion, it was when Elsa was having a debate with her own sister at the coronation party. While having a conflict in her mind, Elsa tried to move away from Anna because she refused Anna for sudden marriage plan. So that Elsa was still be able to control her own emotion, but right after that Anna pulled Elsa glove and argued with her, she suddenly became scared.

c. Social Determinant

In the Kingdom of Arendelle, Elsa was lonely and all alone because she was locked in a room by herself as a result that no one at the kingdom knew about the magical power of Elsa except her own family. Elsa was trying to hide her abnormal power in order to become a normal person because she was afraid that she might hurt people around her. But at the end, the psychological conflict between her and her fear made her difficult to control her emotion and in the end, her power was shown and people knew about her power.

Duke of Weselton: Sorcery. I knew there was something dubious going on here. (Nathan \& Roman, 2013)

Another moment which showed about how people react to Elsa's power was the moment when Elsa ran out from the ballroom to the courtyard of palace. She was welcomed by the people of her own kingdom with applause because she had just became a queen of her own kingdom, but at the moment when she was trying to run away from that place, she accidently touch the fountain and it froze. That accident made a lot of people of the kingdom shocked and showed their fear toward Elsa. As a result they ran away from her.

Duke of Weselton: There she is!

Stop her!

Elsa: Please, just stay away from

me. Stay away!

Duke of Weselton: Monster

Monster! (Nathan \& Roman, 2013)

That moment showed that that the lack of social approval could be influenced by the character or personality development. As a proof that people judged her for the power she had as an abnormal thing and could not accept the fact that she is abnormal as a normal person. Elsa became scared and tried to run away to the north. In conclusion, Elsa should hide her own power and tried to become a normal person. Because of her psychological conflict, she hardly controls her own emotion and power was exposed because of it and people were afraid of her being an abnormal person. People's fear made Elsa's fear became worsen.

d. Aspiration and Achievement

In the novel, it was shown that Elsa failed at achieving her own goal for getting rid of her own fear and power. But after she realized the words of Olaf, Elsa successfully achieved her goal for getting rid of her fear and power.

Elsa : You sacrificed yourself for me?

Anna : I love you.

Olaf : An act of true love

will thaw a frozen heart.

Elsa : Love...will thaw...

Love of course.

Anna : Elsa?

Elsa : Love. (Nathan \&

Roman, 2013)

There is a moment, where Anna sacrificed her life in order to protect Elsa from prince Hans because he is 
trying to swing the sword towards Elsa. Right after that Elsa cried because she saw her own sister froze into an ice sculpture. Elsa's feeling toward Anna made her sister back to normal. That scene could be called as an indirect influenced of achievement, because Elsa realize that only love could get rid of her fear.

e. Family Determinant

In the early life experience, which caused Elsa's character change from cheerful girl into a lonely and gloomy girl. The moment when Elsa accidently knocked Anna's head while they were playing, that was one of the bad experiences of Elsa when she was a child.

Young Anna: Do you want to build a snowman? It doesn't have to be a snowman.

Young Elsa: Go away, Anna.

Young Anna: Okay bye. (Nathan \& Roman, 2013)

In that moment, Anna have the intention on trying to ask Elsa to play with her, but Elsa refused and told her to go away. The reason was because Elsa is scared and still had a conflict with her own fear in controlling her own power. She also did not want Anna to know the fact that she is abnormal. So, Elsa never answered back to Anna whenever Anna go to find her and knocked the door which made Anna feel sad. As it went on until they have become an adult. That was the reason why their communication has becoming bad.

There was a moment where Elsa had a communication with her parents. The main reason on why Elsa trying to get away from Anna was because of her father, the King. The king told Grand Pabbie to protect Elsa and teach Elsa on how to control the power and if she could not control it, it will become a treat to everyone around her. King: No. We'll protect her. She can learn to control it. I'm sure. Until then, we'll lock the gates. We'll reduce the staff. We will limit her contact with people and keep her powers hidden from everyone... including Anna. (Nathan \& Roman, 2013)

There is another moment where It shown about how the King treated Elsa. Everything that the king trying to do to Elsa is to protect her. But because of that, it gave a bad effect to Elsa's personality or character development which could made her became an antisocial person. So as the result, the relationship between Elsa and Anna become bad.

There is a moment where the king treated Elsa badly and Elsa was afraid because of the power of hers. She was scared because whenever she touches something, the thing will freeze because of the power of hers. Then the King told her to wear gloves as protector in order to be aware of freezing something accidently.

King: The gloves will help.

King: See? You're good Conceal it.

Young Elsa: Don't feel it.

Young Elsa \&King: Don't let it show. (Nathan \& Roman, 2013)

The data above shown that Elsa was scared on how the king treated her. The king suggested her to wear gloves so that she will not accidently show her power and tried to calm her down from her fear. The King brainwashed Elsa to be calm and everything will be fine. The psychological conflict had huge effect on Elsa communication with her own family. She tried to distance herself with other people around her Because of the conflict with her own fear. 
Elsa: I'm scared. It's

getting stronger.

King: Getting upset only

makes it worse

Elsa: No. Don't touch me. I

don't want to hurt you.

(Nathan \& Roman, 2013)

The data above shows on how Elsa decline her parent intention for wanted to hug her. The reason why Elsa doesn't want her parent to hug her was because she was afraid that she might hurt her own parents if she touches them with her hand So that she distanced herself away from her family in order to not hurting them accidently.

\section{CONCLUSION}

From the result of analysis above the researcher could conclude that Elsa as the main character had two kinds of psychology conflict, they are approachavoidance conflict and avoidanceavoidance conflict. The first conflict was the approach-avoidance conflict. In this conflict, the researcher found that there are two options of conflict, they were positive and negative. The positive one was she wanted to live happily like a normal person with anyone around her and never be alone anymore. Meanwhile, the negative one was she was really afraid on her uncontrollable power while living closely around everyone around her. The second was the avoidance-avoidance conflict. The researcher found that Elsa has two option for her to choose but whatever she chooses, she will lose. She tried to move far away from the kingdom and be away with her family so that her power will not be exposed to the public. But the more she struggled to resist the fear, the more fear grew, and, in the end, her power was exposed.

The researcher found eight kinds of determinants but only five are found in the character of Elsa, those are intellectual, emotional, social, aspiration \& achievement, and family determinants. As for the first one which is the intellectual determinant, it was associated to the way Elsa made decisions when she was having problem. The second one is the emotional determinant that was associated to her emotion of fear. The third one is the social determinant which was associated to her struggle to live as a normal girl and hide her own power from anyone around her. The fourth one is the aspiration and achievement which were associated to Elsa's goal on trying to get rid of her own fear and power, and the effort she did to achieve the goal. The last was the family determinant which was associated with her communication with her family and how her father treated her.

\section{REFERENCES}

Arianto, T., \& Ambalegin. (2019). Suicide Experiments Due to Unmet Love Needs in Jhumpa Lahiri's Hell-Heaven Story. IdeBahasa, 1(1), 41-50.

Bruno, F. J. (2002). Psychology: A SelfTeaching Guide. New Jersey: Wiley \& Sons Inc.

Drislane, R., \& Parkinson, G. (2011). Qualitative Research. Athabasca University and ICAAP.

Fabdriah, \& Zakrimal. (2017). The Analysis Of Heathcliff Character In Wuthering Heights By Emily Bronte: A Sigmund Freud's THEORY. Jurnal Basis, 4(2), 2942. https://doi.org/ISSN 2527-8835

Hurlock, E. B. (1976). Personality Development. New Delhi: Tata Mc Graw Hill.

Lewin, K. (1957). Approach to Conflict and Its Resolution: A Review with Some Extensions. In The Journal of Conflict Resolution (Vol. 1). Sage Publications, Inc. 
Maslow, A. H. (1954). Motivation and Personalities. Harper \& Row, Publishers, Inc., 395.

Moawad, N. M. I. (2016). A Study of Wole Soyinka's play The Lion and the Jewel in the light of cultures in conflict. International Journal of English and Literature, 7(12), 179-188.

https://doi.org/10.5897/IJEL2016.0 992

Nathan, S., \& Roman, S. (2013). Frozen: The Junior Novelization. Parragon Book Service Ltd. 